\title{
The Effect of Dietary Dry Distilled Rose Petals or Dihydroquercetin Supplementation on the Oxidative Stability and Quality of Lamb Muscles and Fat
}

\author{
Desislava Vlahova-Vangelova ${ }^{1}$, Desislav Balev ${ }^{1(\mathbb{D})}$, Nikolay Kolev ${ }^{1(\mathbb{D})}$, Margarita Terziyska ${ }^{2}{ }^{(\mathbb{D})}$, Stefan \\ Dragoev 1,3 , *
}

1 Department of Meat and Fish Technology, Technological Faculty, University of Food Technologies, 26 Maritza Blvd., 4020 Plovdiv, Bulgaria; desislava_vangelova@abv.bg (D.V.); phdbalev@gmail.com (D.B.); nik0zzz11@gmail.com (N.K.); s.dragoev@uft-plovdiv.bg (S.D.);

2 Department of Informatics and Statistics, Faculty of Economics, University of Food Technologies, 26 Maritza Blvd., 4020 Plovdiv, Bulgaria; m.terziyska@uft-plovdiv.bg (M.T.);

3 Assembly of Academicians and Corresponding Members, Bulgarian Academy of Sciences, 1 "Fifteenth of November" Str., 1040 Sofia, Bulgaria; logos2000lt@gmail.com (S.D.)

* Correspondence: logos2000lt@gmail.com (S.D.);

Scopus Author ID 15727424300

Received: 2.08.2021; Revised: 20.10.2021; Accepted: 23.10.2021; Published: 19.12.2021

\begin{abstract}
The study's objective was to determine the changes in oxidative stability of $\mathrm{m}$. Longissimus dorsi, m. Semimembranosus and perirenal adipose tissue from lambs fed a diet supplemented by $7.5 \mathrm{mg}$ dihydroquercetin/kg life wight/d or $545 \mathrm{mg}$ dry distilled rose petals (DDRP)/kg life wight/d.The experiments were performed with 30 male lambs aged 65 days. They were divided into three groups of 10 animals fed 50 days ad libitum: the control group (with ground alfalfa + granulated compound feed) and two experimental ones (with the same diet + phytonutrients). Samples stored 7 days at $0-4^{\circ} \mathrm{C}$ were examined. After $7 \mathrm{~d}$ of storage in both muscles, the addition of $545 \mathrm{mg}$ DDRP/kg life wight $/ \mathrm{d}$ contributed to the reduction of $\alpha$-aminoacidic nitrogen with approximately $0.5 \mathrm{mg} \mathrm{Leu} / \mathrm{g}$ and the FFA with $0.5-2 \%$. The addition of $7.5 \mathrm{mg}$ dihydroquercetin contributed to the reduction of TBARS with 0.14-0.21 mg MDA $/ \mathrm{kg}$, the total color difference, and a slight increase in the share of the MUFA more pronounced in m. Longissimus dorsi. The reduction of aerobic plate count and total yeasts and molds count were determined too. Further studies with higher doses of phytonutrient's supplementation are needed to determine if it will provoke a more pronounced oxidative stability.
\end{abstract}

Keywords: lambs; phytonutrients; meat; fat; quality.

(C) 2021 by the authors. This article is an open-access article distributed under the terms and conditions of the Creative Commons Attribution (CC BY) license (https://creativecommons.org/licenses/by/4.0/).

\section{Introduction}

The last two decades have seen an increasing demand for organic meat. It is associated with the consumers' concerns about the presence in the meat of residues of pesticides, hormones, and veterinary drugs, including antibiotics [1]. Oxidative stress is another cause of disease-causing pathological changes in ruminants [2]. For these reasons, researchers are increasingly turning their attention to the use of safer alternatives such as plant biologically active feed supplements [3].

Several phytonutrients have been discussed as supplements to ruminant feed, which can be distinguished by their antimicrobial and antioxidant properties and stimulation of the immune effectiveness by modeling the intestinal microflora $[4,5]$. One such phytonutrient is 
flavonol dihydroquercetin [6]. As an electron donor, it can inhibit free hydroxyl radicals and effectively treat microbial infections and inflammatory processes, tumors, cardiovascular and liver diseases, and overcome conditions of oxidative stress. In addition to its confirmed antiinflammatory, cardioprotective, lipid-reducing, capillary-protective, and hepatoprotective effects, it also has membrane-protective, immunomodulatory, antiallergic, detoxifying, angioprotective, and gastroprotective properties [6,7].

Another phytonutrient containing a wide range of polyphenolic components is the dry distilled rose (Rosa damascena Mill.) petals (DDRP). They are a by-product of the distillation of rose oil. They are a source of glycosides of quercetin, kaempferol, and gallic acid, flavonol aglycones, a number of anthocyanins, and quercetin with proven cytotoxic, antioxidant, and antimicrobial activity $[8,9]$.

Oxidation and microbial spoilage are the main reasons for meat deterioration $[10,11]$. They reduce its nutritional value, sensory and functional properties [11,12]. Using the animal's metabolism, supplements of dihydroquercetin and DDRP can be included in the diet to inhibit oxidative processes and microbial spoilage of meat while extending its shelf life [9, 13-16]. The effect of phytonutrients with antioxidant properties is specific to lambs and depends on their dose, metabolism, and the digestive system's specific structure [17].

A limited number of publications discuss the effect of dihydroquercetin or DDRP as antioxidant phytonutrient feed supplements on oxidative stability and meat quality in lambs. Therefore, the objective of this study was to monitor the effect of the supplementation to lamb's diet of low doses of dihydroquercetin or dry distilled rose petals on the oxidative stability and the quality of the lamb muscles and perirenal adipose tissue.

\section{Materials and Methods}

\subsection{Lambs and experimental design.}

The experiments were performed with 30 clinically healthy male lambs aged 65 days and equal in live weight following European Convention for the Protection of Vertebrate Animals used for Experimental and Other Scientific Purposes, Council Regulation (EC) No 1099/2009, Commission Recommendation 2007/526/EC and Bulgarian Veterinary Medical Activity Act. The experiment was approved by the Bulgarian Scientific Ethics Committee, and requirements of the Council Directive 2010/63/EC were met. The lambs were housed indoors in the Experimental Farm of the Agricultural Institute, Shumen, Bulgaria, and were divided into one control and two experimental groups, each containing 10 animals being fed for 50 days. The control group (C) was fed with ground alfalfa + granulated compound feed, and the experimental groups (D) and (R) - with the same diet with the addition of $7.5 \mathrm{mg}$ dihydroquercetin $/ \mathrm{kg} / \mathrm{d}$, or $545 \mathrm{mg}$ of DDRP $/ \mathrm{kg} / \mathrm{d}$. Feeding the lambs was ad libitum in group boxes, with access to water and salt. Individual daily doses of the supplements were calculated according to the previous weighing of the animals, mixed with supplementary feed, and given with the morning feeding. Justification for the applied doses of phytonutrients, the feed composition, and the slaughter procedure was described in detail earlier [18].

After chilling for $24 \mathrm{~h}$ the lamb carcasses were stored at $0-4^{\circ} \mathrm{C}$. On day 1 of chilled storage, the carcasses were divided into two halves. From the left halves in each group, there were separated and collected parts of m. Longissimus thoracis et lumborum (between 9 and 15 thoracic vertebrae, called further as m. Longissimus dorsi), m. Semimembranosus and perirenal adipose tissue (fat). Chilled muscle samples were ground in a mincer with a holes' diameter of 
$3 \mathrm{~mm}$ after that, were blended on a homogenizer. The same procedure was repeated with the right carcass halves on $7 \mathrm{~d}$ of the chilled storage. The values of the studied indicators were determined as the average of nine repetitions.

\subsection{Phytonutrients and diet.}

The experimental groups (D) and (R) were fed the same diet supplemented with $7.5 \mathrm{mg}$ dihydroquercetin/kg/day or $545 \mathrm{mg}$ DDRP/kg/day. The reasons why the above doses were used are presented in our previous publication [18].

Daily control of the amount of combined feed consumption during the experiment was exercised. Residual feed was weighed and subtracted from the daily amount of feed consumed. Lambs were weighed every two weeks.

The dihydroquercetin powder isolate was supplied by Flavitlife Bio JSCo (Sofia, Bulgaria). It had a purity of $96 \%$. In addition to dihydroquercetin, the preparation contains $3 \%$ dihydrokaempferol and $1 \%$ naringenin.

The dry distilled rose petals (DDRP) were delivered by Bulattars Production Company Ltd (Pavel banya, Stara Zagora region, Bulgaria). After pressing, the petals were dried (24 hours, $65^{\circ} \mathrm{C}$ ) and ground to a particle size $<0.4 \mathrm{~mm}$. The 13 glycosides of kaempferol, 10 glycosides of quercetin, 6 glycosides of gallic acid, and 2 flavonol aglycones were identified in dry rose petals. The daily dose of the supplements was calculated according to the previous one and mixed with feed mixture [18] and given to the lambs with the morning feeding.

\subsection{Determination of $\alpha$-aminoacidic nitrogen.}

The content of $\alpha$-aminoacidic nitrogen in lamb was determined by the ninhydrin method with small modifications [19, 20].

\subsection{Extraction of the total lipids.}

Extraction of the total lipids was performed by the method of Bligh and Dyer [21].

\subsection{Free fatty acids determination.}

The acid value (AV) of the extracted total lipids was determined according to the procedure of EVS-EN ISO 660:2009 [22]. The extracted lipids were dissolved in ethyl alcohol (99\%), heated for 2 min before titration while still hot against $0.1 \mathrm{M} \mathrm{NaOH}$ using phenolphthalein as an indicator. Free fatty acids FFA $(\%)$ were calculated as $0.503 \times \mathrm{AV}$.

\subsection{Peroxide value.}

The peroxide value (POV) was measured based on the oxidation of $\mathrm{Fe}^{2+}$ to $\mathrm{Fe}^{3+}$ in the presence of hydroperoxides and the formation of a color complex between the obtained $\mathrm{Fe}^{3+}$ and SCN with some modification [23]. The extracted lipids $(0.1 \mathrm{~g})$ were mixed with $50 \mu 1$ $\mathrm{FeCl}_{2}, 50 \mu 1 \mathrm{NH}_{4} \mathrm{SCN}$ and $\mathrm{CHCl}_{3}: \mathrm{CH}_{3} \mathrm{OH}(3: 5, \mathrm{v} / \mathrm{v})$ to a volume of $10 \mathrm{ml}$. The sample was left for $10 \mathrm{~min}$. The absorbance was measured at $507 \mathrm{~nm}$ using double beam UV-Vis spectrophotometer Camspec M 550 (Spectronic CamSpec Ltd, Garforth, Leeds, United Kingdom) against a control sample prepared from $1 \mathrm{~g}$ of total lipids, $50 \mu 1 \mathrm{NH}_{4} \mathrm{SCN}, \mathrm{CHCl}_{3}$ : $\mathrm{CH}_{3} \mathrm{OH}(3: 5, \mathrm{v} / \mathrm{v})$ to a volume of $10 \mathrm{ml}$. 


\subsection{TBARS.}

TBARS were measured spectrophotometrically at $532 \mathrm{~nm}$ using Botsoglou et al. [24] using a double beam UV-Vis spectrophotometer Camspec M 550 (Spectronic CamSpec Ltd, Garforth, Leeds, United Kingdom).

\subsection{Fatty acids analysis.}

The fatty acid composition of the extracted total lipids was determined by gas chromatography (GC) after transmethylation of the samples with $2 \% \mathrm{H}_{2} \mathrm{SO}_{4}$ in absolute $\mathrm{CH} 3 \mathrm{OH}$ at $50^{\circ} \mathrm{C}$ [25]. Fatty acid methyl esters (FAME) were purified by thin-layer chromatography (TLC) on 20x20 cm plates coated with $0.2 \mathrm{~mm}$ silica gel $60 \mathrm{G}$ (Merck) layer with a mobile phase n-hexane: diethyl ether (97: 3, v/ v). Gas chromatographic analysis of the FAME was performed on a GC gas chromatograph Agilent 6890 Plus (Agilent Technologies, Santa Clara, USA) equipped with 5793 mass-selective detectors (Agilent Technologies, Santa Clara CA, USA) and with capillary column SP $2380(30 \mathrm{mx} 0.25 \mathrm{~mm}$ x $0.25 \mu \mathrm{m}$, Supelco, Bellefonte PA, USA). The column temperature was programmed from $70^{\circ} \mathrm{C}(1 \mathrm{~min})$, at $6^{\circ} \mathrm{C} / \mathrm{min}$ to $190^{\circ} \mathrm{C}(0 \mathrm{~min})$, at $10^{\circ} \mathrm{C} / \mathrm{min}$ to $250^{\circ} \mathrm{C}(0 \mathrm{~min})$; the injector and detector temperatures are maintained at $250^{\circ} \mathrm{C}$. Hydrogen was a carrier gas at a $0.8 \mathrm{ml} / \mathrm{min}$ flow rate, and the separation was 1: 50. The identification of fatty acids was performed by comparing the retention times with those of a standard mixture of fatty acids subjected to GC under identical experimental conditions [26].

\subsection{Determination of the meat color characteristics.}

The color of the meat was determined in three places on both sides of the twocentimeter cross-section made perpendicular to the muscle fibers $(24 \mathrm{~h}$ and after chilling the samples to $0-4^{\circ} \mathrm{C}$ on $7 \mathrm{~d}$ post mortem), after which the values were averaged. The color characteristics of the samples were examined with a Konica Minolta chromameter model CR410 using the CIE L*, a*, b* system [27].

The total color difference $(\Delta \mathrm{E})$ was also calculated by equation (4):

$$
\Delta E=\sqrt{\left(L_{2}^{*}-L_{1}^{*}\right)^{2}+\left(a_{2}^{*}-a_{1}^{*}\right)^{2}+\left(b_{2}^{*}-b_{1}^{*}\right)^{2}} \quad(4), \quad \text { where: }
$$

$\Delta \mathrm{E}$ is the total color difference and $\Delta \mathrm{L}^{*}, \Delta \mathrm{a}^{*}$ and $\Delta \mathrm{b}^{*}$ are the differences in the values of the brightness $\left(\mathrm{L}^{*}\right)$, the red component $\left(\mathrm{a}^{*}\right)$, and the yellow component $\left(\mathrm{b}^{*}\right)$ between the control sample and the corresponding experimental one [28].

\subsection{Determination of the microbiological status of lamb meat.}

The microbiological status of the samples was established through bacteriological tests carried out following the microbiological criteria of Regulation (EC) № 1441 of 05.12.2007 using ISO 4833:2001 [29].

\subsection{Statistical analyses.}

A two-way analysis of variance (ANOVA) was used to evaluate the effect of the addition of the two phytonutrients and the chilled storage time on the studied parameters: $\alpha$ aminoacidic nitrogen, FFA, POV, TBARS, color characteristics $\left(\mathrm{L}^{*}, \mathrm{a}^{*}, \mathrm{~b}^{*}, \Delta \mathrm{E}\right)$ and microbiological status of the lamb. The data analysis was performed with the statistical package 
Microsoft Excel Office Professional Plus 2010. The differentiation of the mean values was performed using Fisher's test, and significant differences $(\mathrm{P} \leq 0.05)$ between the treatments were found. The results obtained are presented as mean \pm standard deviation (mean \pm SD).

\section{Results and Discussion}

\section{1. $\alpha$-Aminoacidic nitrogen.}

The data from Fig. 1 show that on $1 \mathrm{~d}$ post mortem the levels of $\alpha$-aminoacidic nitrogen in the studied samples fluctuated within narrow limits (between $2.12-2.51 \mathrm{mg} / \mathrm{g}$ ) and did not significantly differ $(\mathrm{p}>0.05)$. After $7 \mathrm{~d}$ of storage of the lamb muscles, proteolytic changes were observed, and the content of $\alpha$-aminoacidic nitrogen increased $2.68-4.08$ times. This increase was more pronounced in control $\mathrm{C}$ and samples $\mathrm{D}$ in both muscles. The increased levels of $\alpha$-aminoacidic nitrogen in the controls are probably due to the reduced activity of $\mathrm{Ca}^{2+}$-ATPase and the increased activity of $\mathrm{Mg}^{2+}$-EGTA-ATPase, enzymes responsible for the denaturation of myosin and troponin-tropomyosin complex in muscle fibers [30]. It was found that after $7 \mathrm{~d}$ of chilled storage, the lamb's feed supplementation of $545 \mathrm{mg}$ DDRP $/ \mathrm{kg} / \mathrm{d}$ reduced the accumulation of $\alpha$-aminoacidic nitrogen by $14.5 \%$ in $\mathrm{m}$. Longissimus dorsi and by $7.3 \%$ in m. Semimembranosus respectively.

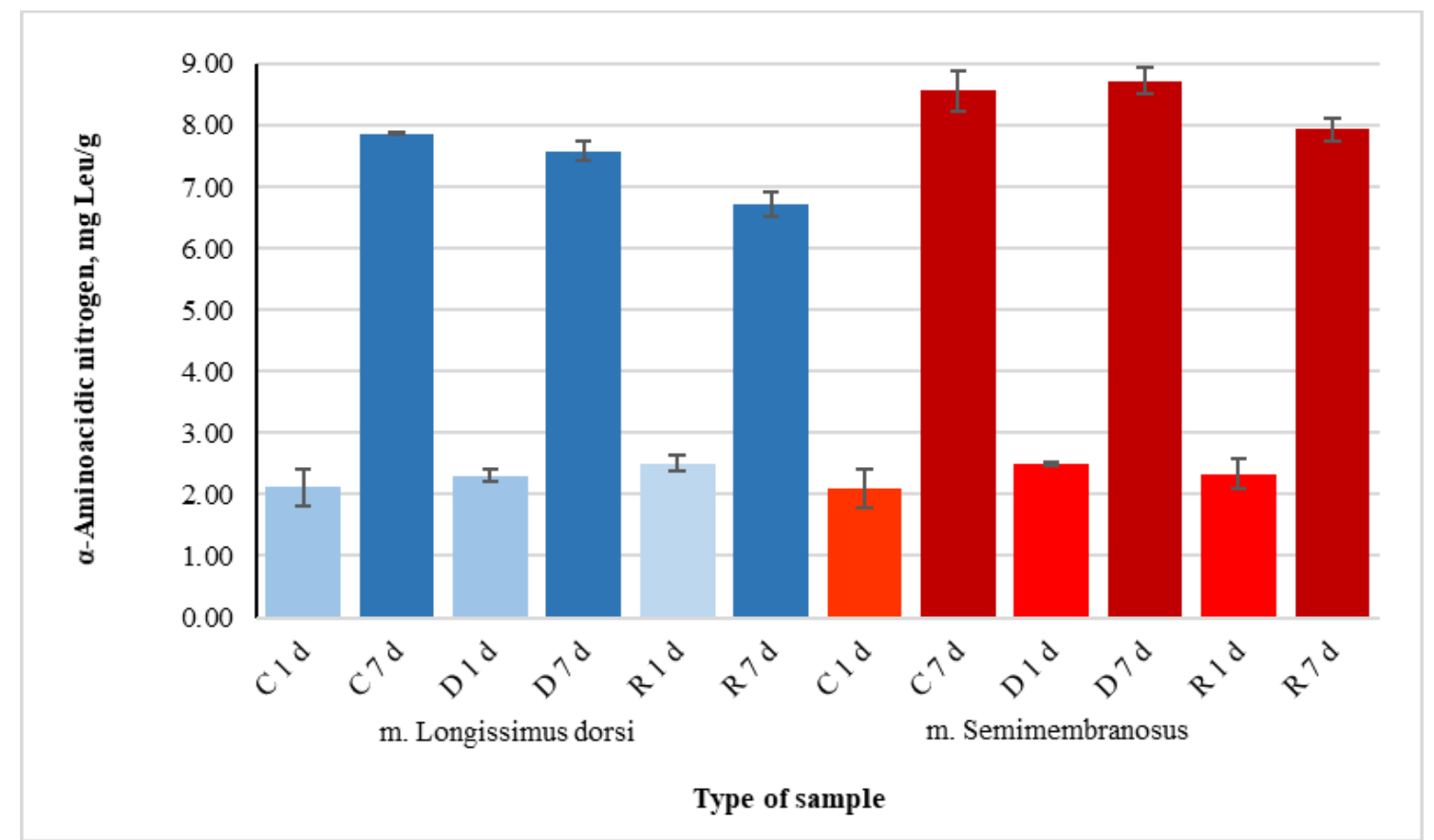

Figure 1. Changes of the $\alpha$-aminoacidic nitrogen of lamb's m. Longissimus dorsi and m. Semimembranosus after $7 \mathrm{~d}$ storage at $0-4^{\circ} \mathrm{C}$.

This phenomenon is more pronounced in samples $\mathrm{R}$ from $\mathrm{m}$. Longissimus dorsi. Presumably, the heavy myosin chain and troponin $\mathrm{T}$ undergo significant hydrolytic degradation while actin remains relatively stable during meat refrigeration [31]. Polyphenols from DDRP may inhibit muscle proteolytic enzyme systems in vivo [16]. Biologically active substances such as polyphenols can affect the molecular mechanisms of control of genes, affecting cellular metabolism [31]. The mechanism of this interaction is still unclear. It depends on various factors such as the efficiency of their assimilation, their active concentrations in muscle tissue, metabolic transformation after absorption, which would rather reduce their antioxidant properties [16]. 


\subsection{Free fatty acids (FFA).}

The data from Fig. 2 demonstrate that $1 \mathrm{~d}$ post mortem FFA found in samples D and $\mathrm{R}$ in $\mathrm{m}$. Longissimus dorsi was $13.8-19.5 \%$ less $(\mathrm{p} \leq 0.05)$ compared to control one C. In $\mathrm{m}$. Semimembranosus and perirenal adipose tissue FFA are less by approx. $41.2 \%$ and resp. $14.7 \%$ only in samples R. A similar trend was found after $7 \mathrm{~d}$ storage of lamb muscles. The lowest levels of FFA were found in samples D in m. Semimembranosus - by $17.5 \%$, in perirenal adipose tissue - by $26.3 \%$ and in $\mathrm{m}$. Longissimus dorsi by more than $52 \%$ compared to control samples $\mathrm{C}$.

These results give us reason to hypothesize that the weaker increase in free fatty acid levels in the samples obtained from lambs fed with feed supplemented with $545 \mathrm{mg}$ DDRP $/ \mathrm{kg} / \mathrm{d}$ is probably also due to an inhibition of the activity of endogenous lipolytic enzyme systems in ruminants [2].

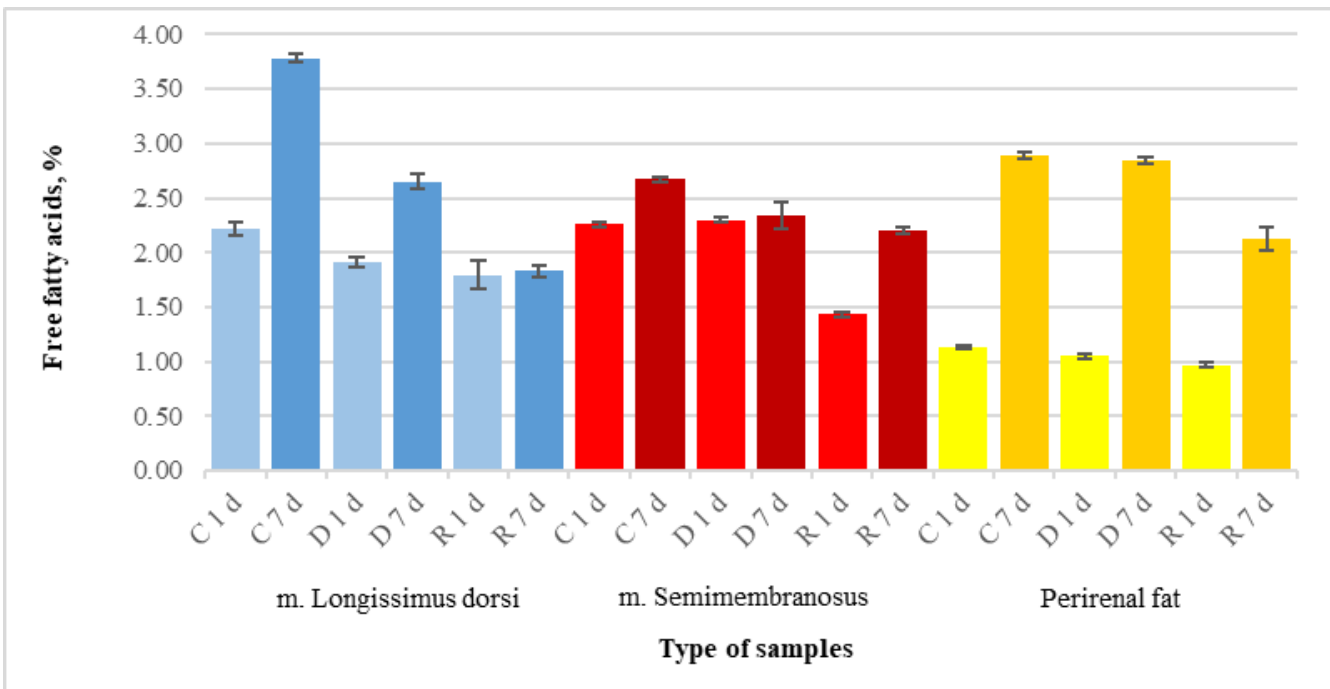

Figure 2. Changes of the percentage of free fatty acids in total lipids extracted from lamb's m. Longissimus dorsi, m. Semimembranosus and perirenal fatty tissue after $7 \mathrm{~d}$ storage at $0-4^{\circ} \mathrm{C}$.

\subsection{Peroxide value (POV).}

Both on $1 \mathrm{~d}$ post mortem and after $7 \mathrm{~d}$ of the storage (Table 1), relatively low levels of primary lipid oxidation products (POV) were found.

It was observed that both in the samples of fresh muscle and perirenal adipose tissue (1 $\mathrm{d}$ post mortem) and those after $7 \mathrm{~d}$ of storage, the POV varied between $0.103-0.119 \mu \mathrm{eqO} / \mathrm{g}$ lipids but the differences were not significant ( $\mathrm{p}>0.05)$. Significantly higher levels of POV $\left(0.126 \mu \mathrm{eqO} \mathrm{O}_{2} / \mathrm{g}\right.$ lipids) were found in controls $\mathrm{C}$ in $\mathrm{m}$. Semimembranosus only on $1 \mathrm{~d}$ post mortem. Our results correspond to the available data that the total peroxides in lamb were less than in beef or pork [33]. Hydroperoxides are unstable structures. They undergo transformations and turn into lower molecular secondary lipid oxidation products, and at $4{ }^{\circ} \mathrm{C}$ such reactions need $24-36 \mathrm{~h}$ [33]. This explains the lower POV we found on $7 \mathrm{~d}$ stored chilled meat. The formation of approximately $70 \%$ of the non-polar peroxides was due to the change in fatty acid composition and heme iron content in meat [33]. The results showed that the feed supplements of $7.5 \mathrm{mg}$ dihydroquercetin/ $\mathrm{kg} / \mathrm{d}$ and $545 \mathrm{mg}$ DDRP $/ \mathrm{kg} / \mathrm{d}$ when feeding lambs were not sufficient to support the lamb's own integrated antioxidant system and to prevent the negative effects of free radicals and the reactive oxygen species of their metabolism [2, 34]. 
Table 1. Primary and secondary products of lipid oxidation determined in lamb's m. Longissimus dorsi, $\mathrm{m}$.

Semimembranosus and perirenal adipose tissue stored $7 \mathrm{~d}$ at $0-4^{\circ} \mathrm{C}$.

\begin{tabular}{|c|c|c|c|c|c|c|c|c|c|}
\hline \multirow[t]{2}{*}{ Samples } & \multicolumn{3}{|c|}{ m. Longissimus dorsi } & \multicolumn{3}{|c|}{ m. Semimembranosus } & \multicolumn{3}{|c|}{ Perirenal adipose tissue } \\
\hline & C & D & $\mathbf{R}$ & C & D & $\mathbf{R}$ & $\mathbf{C}$ & D & $\mathbf{R}$ \\
\hline $\begin{array}{l}\text { Peroxide value, } \\
\mu \mathrm{egO} \mathrm{O}_{2} / \mathrm{g} \text { fat } 1 \mathrm{~d}\end{array}$ & $\begin{array}{l}0.111 \pm \\
0.010 \text { ay }\end{array}$ & $\begin{array}{l}0.119 \pm \\
0.009 \text { ay }\end{array}$ & $\begin{array}{l}0.112 \pm \\
0.001 \text { ay }\end{array}$ & $\begin{array}{l}0.126 \pm \\
0.005 \mathrm{bz}\end{array}$ & $\begin{array}{l}0.116 \pm \\
0.008 a z\end{array}$ & $\begin{array}{l}0.113 \pm \\
0.003 a z\end{array}$ & $\begin{array}{l}0.108 \pm \\
0.010 a z\end{array}$ & $\begin{array}{l}0.103 \pm \\
0.005 \text { ay }\end{array}$ & $\begin{array}{l}0.106 \pm \\
0.005 \text { ay }\end{array}$ \\
\hline $\begin{array}{l}\text { Peroxide value, } \\
\mu \mathrm{eqO} / \mathrm{g} \text { fat } 7 \mathrm{~d}\end{array}$ & $\begin{array}{l}0.113 \quad \pm \\
0.004 \text { ay }\end{array}$ & $\begin{array}{l}0.112 \pm \\
0.003 \text { ay }\end{array}$ & $\begin{array}{l}0.111 \quad \pm \\
0.003 \text { ay }\end{array}$ & $\begin{array}{l}0.109 \quad \pm \\
0.004 \text { ay }\end{array}$ & $\begin{array}{l}0.108 \quad \pm \\
0.003 \text { ay }\end{array}$ & $\begin{array}{l}0.112 \quad \pm \\
0.007 \text { ay }\end{array}$ & $\begin{array}{l}0.103 \quad \pm \\
0.002 \text { ay }\end{array}$ & $\begin{array}{l}0.107 \quad \pm \\
0.003 a z\end{array}$ & $\begin{array}{l}0.106 \quad \pm \\
0.005 \text { ay }\end{array}$ \\
\hline $\begin{array}{ll}\text { TBARS, } & \mathrm{mg} \\
\text { MDA/kg } & 1 \mathrm{~d}\end{array}$ & $\begin{array}{l}0.43 \pm \\
0.04 \text { by }\end{array}$ & $\begin{array}{l}0.39 \pm \\
0.06 \text { by }\end{array}$ & $0.64 \pm$ & $\begin{array}{l}0.70 \pm \\
0.02 e y^{ \pm}\end{array}$ & $\begin{array}{l}0.59 \pm \\
0.01 d y\end{array}$ & $\begin{array}{l}0.53 \pm \\
0.01 \mathrm{cy}^{ \pm}\end{array}$ & $\begin{array}{l}0.24 \pm \\
0.03 a y\end{array}$ & $\begin{array}{l}0.20{ }^{ \pm} \pm \\
0.03 a^{2}\end{array}$ & $\begin{array}{l}0.79 \pm \\
0.01 \mathrm{ez}\end{array}$ \\
\hline $\begin{array}{lr}\text { TBARS, } & \mathrm{mg} \\
\mathrm{MDA} / \mathrm{kg} & 7 \mathrm{~d}\end{array}$ & $\begin{array}{l}0.57 \pm \\
0.10 d z\end{array}$ & $\begin{array}{l}0.43 \quad \pm \\
0.01 c z\end{array}$ & $\begin{array}{l}0.64{ }^{ \pm} \\
0.05 e^{2}\end{array}$ & $\begin{array}{l}0.93 \pm \\
0.05 \mathrm{iz}\end{array}$ & $\begin{array}{l}0.72 \pm \\
0.03 f z\end{array}$ & $\begin{array}{l}0.77 \pm \\
0.04 \mathrm{gz}\end{array}$ & $\begin{array}{l}0.26 \pm \\
0.03 a z\end{array}$ & $\begin{array}{l}0.28 \pm \\
0.03 \mathrm{bz}\end{array}$ & $\begin{array}{l}0.43 \pm \\
0.03 c y\end{array}$ \\
\hline
\end{tabular}

* Different letters $(a, b, c, d, e, f, g, i)$ within the same row indicate significant differences $(\mathrm{p} \leq 0.05)$;

Different letters $(y, z)$ within the same column indicate significant differences $(\mathrm{p} \leq 0.05) ; \mathrm{n}=9$; SD - standard deviation;

\subsection{TBARS.}

Relatively low TBARS values were found on $1 \mathrm{~d}$ post mortem and after $7 \mathrm{~d}$ of the storage (Table 1). They were ten times as low as the values of TBARS $(\leq 5 \mathrm{mg} \mathrm{MDA} / \mathrm{kg})$ indicated as the threshold for detecting unpleasant odors and tastes in meat [11, 34]. Similar to our results, there were reported significant differences in malondialdehyde content after $3 \mathrm{~d}$ of chilled storage of rabbit meat [30]. On $1 \mathrm{~d}$ post mortem in lamb muscles, TBARS were statistically $(\mathrm{p} \leq 0.05$ ) distinguishable but varied within a very small range $0.39-0.70 \mathrm{mg}$ $\mathrm{MDA} / \mathrm{kg}$ without a one-way trend. For example, in $\mathrm{m}$. Longissimus dorsi and in the perirenal adipose tissue, the lowest levels of TBARS were found in samples D. Their values did not differ significantly $(\mathrm{p}>0.05)$ from those of control C. In m. Semimembranosus the lowest levels of TBARS were found in samples R. In samples D in $\mathrm{m}$. Longissimus dorsi and $\mathrm{m}$. Semimembranosus the lowest levels of TBARS were recorded even after $7 \mathrm{~d}$ of lamb storage by $24.5 \%$ and $22.5 \%$, respectively. The results obtained can be explained by the fact that the oxidation of lipids and proteins in meat is closely related [32]. The major substance that reacts with TBA to form an adduct absorbing at $532 \mathrm{~nm}$ is MDA. To form dimers or trimers, it can react with a wide range of compounds such as amines, amino acids, amino sugars, proteins, and nucleosides. Such chemical transformations practically remove MDA from the reaction system. Its amount decreases, which lowers the concentration of the MDA-TBA complex, and the reported values for TBARS are lower [35]. This explains the relatively lower TBARS values that were reported after $7 \mathrm{~d}$ of chilled storage (Table 1). On the other hand, the endogenous antioxidant defense system of the muscles remains active for several days after the animal death. This answers why the statistical differences in TBARS values are more significant only after $7 \mathrm{~d}$ refrigeration [33]. The obtained results allow us to conclude that the supplementation of $7.5 \mathrm{mg}$ dihydroquercetin/ $\mathrm{kg} / \mathrm{d}$ to the lamb's diet can be used as a good tool for inhibiting lipid oxidation processes in m. Longissimus dorsi and m. Semimembranosus and of reducing the content of secondary products of lipid oxidation by more than $20 \%$. Such a conclusion cannot be drawn for perirenal adipose tissue. The concentration of the 11 studied supplements of two phytonutrients is not sufficient to have an inhibitory effect on lipid oxidation. Lower TBARS levels with supplementation of $7.5 \mathrm{mg}$ dihydroquercetin/ $\mathrm{kg} / \mathrm{d}$ to the lamb's diet demonstrate a positive connection between the intake of this $96 \%$ flavonol isolate and the lamb's antioxidant protection in vivo [36].

Even though flavonoids are not well absorbed in the intestines of ruminants, even with the indicated intake of $7.5 \mathrm{mg}$ dihydroquercetin $/ \mathrm{kg} / \mathrm{d}$, there is clear antioxidant protection [34]. It could also be due to the antioxidant activity of the zinc dihydroquercetin complex, which can 
reduce the MDA content and enhance the catalase activity [37]. Obviously, oxidative processes in the muscle lipids are provoked during the lamb refrigeration. As a result of the dynamic transformation of some of the primary lipid peroxidation products, secondary products accumulate relatively lower levels of TBARS in $\mathrm{m}$. Longissimus dorsi compared to $\mathrm{m}$. Semimembranosus testifies to its stronger oxidative stability due to the more active antioxidant enzyme superoxide dismutase (SOD) and catalase. These enzymes slow down lipid oxidation. They can reduce the superoxide anion and remove hydrogen peroxide from the system [38].

\subsection{Fatty acid composition.}

No one-way trends in the influence of the supplementation of feed phytonutrients (7.5 $\mathrm{mg}$ dihydroquercetin $/ \mathrm{kg} / \mathrm{d}$ or $545 \mathrm{mg} \mathrm{DDRP} / \mathrm{kg} / \mathrm{d}$ ) or $7 \mathrm{~d}$ chilled storage on the fatty acid compositions of the samples (Table 2). With aging, when goats are fed dry diets containing natural phytonutrients, the content of stearic acid (C18:0) in fat depots decreases, but with increasing the live weight, the levels of saturated fatty acids increase at the expense of monounsaturated ones [39]. The data for lamb's perirenal adipose tissue confirmed the claims of previous researches with the exception of the stearic acid levels (C18:0) in samples D found on $1 \mathrm{~d}$ post mortem [39]. Compared to controls $\mathrm{C}$, after $7 \mathrm{~d}$ of storage of the samples, the levels of SFA decrease by approx. 5\% at the expense of a similar increase in MUFA was found only in samples D of m. Longissimus dorsi (Table 2).

Table 2. Changes of fatty acid profiles of total lipids extracted from lamb's m. Longissimus dorsi, $\mathrm{m}$.

Semimembranosus and perirenal fatty tissue after $7 \mathrm{~d}$ storage at $0-4^{\circ} \mathrm{C}$

\begin{tabular}{|c|c|c|c|c|c|c|c|c|c|}
\hline \multirow{2}{*}{$\begin{array}{l}\text { Samples } \\
\text { Fatty acid, } \\
\% \text { of FAME }\end{array}$} & \multicolumn{3}{|c|}{ m. Longissimus dorsi } & \multicolumn{3}{|c|}{ m. Semimembranosus } & \multicolumn{3}{|c|}{ Perirenal fatty tissue } \\
\hline & $\mathbf{C}$ & D & $\mathbf{R}$ & $\mathbf{C}$ & D & $\mathbf{R}$ & $\mathbf{C}$ & D & $\mathbf{R}$ \\
\hline C $12: 0-1 d$ & $0.2 \pm 0.02$ & $0.1 \pm 0.01$ & $0.2 \pm 0.03$ & $0.1 \pm 0.05$ & $0.5 \pm 0.02$ & $0.6 \pm 0.03$ & $0.3 \pm 0.01$ & $0.5 \pm 0.03$ & $0.9 \pm 0.03$ \\
\hline C $12: 0-7 d$ & $0.2 \pm 0.03$ & $0.2 \pm 0.03$ & $0.3 \pm 0.02$ & $0.4 \pm 0.01$ & $0.5 \pm 0.04$ & $0.5 \pm 0.05$ & $0.3 \pm 0.03$ & $0.4 \pm 0.02$ & $0.2 \pm 0.03$ \\
\hline C $14: 0-1 \mathrm{~d}$ & $2.5 \pm 0.06$ & $5.8 \pm 0.03$ & $3.4 \pm 0.02$ & $2.8 \pm 0.07$ & $5.1 \pm 0.08$ & $4.8 \pm 0.08$ & $2.9 \pm 0.06$ & $4.3 \pm 0.03$ & $6.2 \pm 0.05$ \\
\hline C 14:0-7d & $2.8 \pm 0.05$ & $2.6 \pm 0.04$ & $3.2 \pm 0.05$ & $3.0 \pm 0.06$ & $3.8 \pm 0.05$ & $4.2 \pm 0.05$ & $2.5 \pm 0.01$ & $4.3 \pm 0.04$ & $2.9 \pm 0.05$ \\
\hline C $15: 0-1 d$ & $0.1 \pm 0.04$ & $0.7 \pm 0.01$ & $0.4 \pm 0.03$ & $0.4 \pm 0.03$ & $0.5 \pm 0.03$ & $0.4 \pm 0.02$ & 0.0 & $0.1 \pm 0.04$ & $0.1 \pm 0.01$ \\
\hline C 15:0-7d & $0.4 \pm 0.04$ & $0.5 \pm 0.03$ & $0.4 \pm 0.02$ & $0.4 \pm 0.01$ & $0.6 \pm 0.02$ & $0.5 \pm 0.06$ & $0.4 \pm 0.03$ & $0.5 \pm 0.01$ & $0.5 \pm 0.03$ \\
\hline C 16:0 - 1d & $23.2 \pm 0.08$ & $34.4 \pm 0.02$ & $25.3 \pm 0.05$ & $22.5 \pm 0.10$ & $29.3 \pm 0.11$ & $28.6 \pm 0.10$ & $19.0 \pm 0.08$ & $23 . \pm 0.07$ & $29.8 \pm 0.02$ \\
\hline C 16:0-7d & $22.9 \pm 0.05$ & $25.1 \pm 0.10$ & $30.5 \pm 0.11$ & $23.2 \pm 0.14$ & $28.2 \pm 0.10$ & $29.2 \pm 0.11$ & $21.4 \pm 0.05$ & $23.1 \pm 0.10$ & $29.9 \pm 0.05$ \\
\hline C $16: 1-1 d$ & $1.4 \pm 0.01$ & $1.9 \pm 0.06$ & $2.0 \pm 0.08$ & $1.4 \pm 0.02$ & $2.1 \pm 0.04$ & $1.5 \pm 0.02$ & $0.9 \pm 0.01$ & $1.6 \pm 0.05$ & $1.6 \pm 0.08$ \\
\hline C 16:1 - $7 d$ & $1.2 \pm 0.03$ & $2.2 \pm 0.04$ & $1.4 \pm 0.09$ & $1.3 \pm 0.06$ & $2.0 \pm 0.10$ & $1.5 \pm 0.04$ & $1.3 \pm 0.03$ & $1.7 \pm 0.07$ & $2.1 \pm 0.04$ \\
\hline C $17: 0-1 d$ & $1.4 \pm 0.03$ & $1.7 \pm 0.02$ & $1.4 \pm 0.05$ & $1.3 \pm 0.03$ & $1.4 \pm 0.06$ & $1.0 \pm 0.01$ & $1.6 \pm 0.02$ & $2.4 \pm 0.05$ & $1.3 \pm 0.05$ \\
\hline C 17:0 - $7 \mathrm{~d}$ & $1.5 \pm 0.09$ & $1.9 \pm 0.07$ & $1.3 \pm 0.04$ & $1.3 \pm 0.03$ & $2.0 \pm 0.10$ & $1.5 \pm 0.07$ & $1.7 \pm 0.10$ & $1.7 \pm 0.01$ & $1.6 \pm 0.06$ \\
\hline C 17:1 - 1d & $0.5 \pm 0.03$ & $0.5 \pm 0.06$ & $0.8 \pm 0.04$ & $0.5 \pm 0.01$ & $0.6 \pm 0.02$ & $0.7 \pm 0.05$ & $0.3 \pm 0.04$ & $0.5 \pm 0.02$ & $0.5 \pm 0.04$ \\
\hline C $17: 1-7 d$ & $0.4 \pm 0.02$ & $1.1 \pm 0.02$ & $0.5 \pm 0.03$ & $0.5 \pm 0.03$ & $0.6 \pm 0.02$ & $0.7 \pm 0.06$ & $0.5 \pm 0.08$ & $0.6 \pm 0.03$ & $0.8 \pm 0.02$ \\
\hline C 18:0 - 1 d & $13.5 \pm 0.10$ & $15.5 \pm 0.07$ & $12.7 \pm 0.08$ & $15.1 \pm 0.08$ & $13.2 \pm 0.13$ & $14.5 \pm 0.09$ & $21.7 \pm 0.10$ & $23.5 \pm 0.17$ & $16.8 \pm 0.11$ \\
\hline C $18: 0-7 d$ & $18.3 \pm 0.05$ & $10.5 \pm 0.10$ & $17.2 \pm 0.15$ & $16 . \pm 0.10$ & $11.8 \pm 0.16$ & $17.4 \pm 0.06$ & $18.3 \pm 0.05$ & $15.1 \pm 0.16$ & $11 . \pm 0.14$ \\
\hline C $18: 1-1 d$ & $48.8 \pm 0.13$ & $33.4 \pm 0.11$ & $47.9 \pm 0.08$ & $49.1 \pm 0.17$ & $40.1 \pm 0.08$ & $42.5 \pm 0.19$ & $45.2 \pm 0.10$ & $36.7 \pm 0.15$ & $40.6 \pm 0.11$ \\
\hline C $18: 1-7 d$ & $47.4 \pm 0.11$ & $51.0 \pm 0.06$ & $41.5 \pm 0.10$ & $47.0 \pm 0.05$ & $46.5 \pm 0.12$ & $39.9 \pm 0.19$ & $49.5 \pm 0.06$ & $48.0 \pm 0.21$ & $47.9 \pm 0.13$ \\
\hline C $18: 2-1 d$ & $7.1 \pm 0.08$ & $3.9 \pm 0.05$ & $4.9 \pm 0.02$ & $5.9 \pm 0.07$ & $5.4 \pm 0.05$ & $4.6 \pm 0.03$ & $7.1 \pm 0.07$ & $5.9 \pm 0.08$ & $0.8 \pm 0.04$ \\
\hline C $18: 2-7 d$ & $4.7 \pm 0.07$ & $4.6 \pm 0.04$ & $3.2 \pm 0.05$ & $6.1 \pm 0.05$ & $4.0 \pm 0.06$ & $4.5 \pm 0.08$ & $3.6 \pm 0.05$ & $4.3 \pm 0.05$ & $2.2 \pm 0.03$ \\
\hline C $18: 3-1 d$ & $0.4 \pm 0.03$ & $1.6 \pm 0.02$ & $0.3 \pm 0.03$ & $0.6 \pm 0.04$ & $0.9 \pm 0.05$ & $0.1 \pm 0.01$ & $0.6 \pm 0.02$ & $0.8 \pm 0.03$ & $0.6 \pm 0.01$ \\
\hline C $18: 3-7 d$ & 0.0 & 0.0 & $0.2 \pm 0.03$ & $0.2 \pm 0.02$ & 0.0 & 0.0 & $0.1 \pm 0.02$ & 0.0 & 0.0 \\
\hline $\mathrm{SFA}-1 \mathrm{~d}$ & $41.7 \pm 0.01^{a y}$ & $58.6 \pm 0.011^{i z}$ & $44.0 \pm 0.01^{c y}$ & $42.4 \pm 0.02^{b y}$ & $50.7 \pm \mathbf{0 . 0 8}^{e z}$ & $50.5 \pm 0.05^{e y}$ & $45.7 \pm 0.03^{d z}$ & $54.3 \pm 0.02^{f z}$ & $55.7 \pm 0.04^{g z}$ \\
\hline SFA - 7d & $46.3 \pm 0.08^{d z}$ & $41.0 \pm 0.08^{a y}$ & $53.2 \pm 0.04^{e z}$ & $44.8 \pm 0.08^{b z}$ & $46.8 \pm 0.04^{d y}$ & $53.3 \pm 0.08^{e z}$ & $44.9 \pm 0.04^{b y}$ & $45.3 \pm 0.08^{c y}$ & $46.9 \pm 0.01^{d}$ \\
\hline UFA $-1 d$ & $58.3 \pm 0.02^{i z}$ & $41.4 \pm 0.08^{a y}$ & $56.0 \pm 0.04^{f z}$ & $57.6 \pm 0.03^{g z}$ & $49.3 \pm 0.02^{d y}$ & $49.5 \pm 0.06^{d z}$ & $54.3 \pm 0^{0.08}{ }^{e y}$ & $45.7 \pm 0.02^{c y}$ & $44.3 \pm 0.04^{b_{y}}$ \\
\hline UFA $-7 \mathrm{~d}$ & $53.7 \pm 0.08^{b y}$ & $59.0 \pm 0.044^{e z}$ & $46.9 \pm 0.03^{a y}$ & $55.2 \pm 0.04^{d y}$ & $53.2 \pm 0.05^{b z}$ & $46.7 \pm 0.04^{a y}$ & $55.1 \pm 0^{0.08}{ }^{d z}$ & $54.7 \pm 0.03^{c z}$ & $53.1 \pm 0.04^{b z}$ \\
\hline MUFA - $1 \mathrm{~d}$ & $50.8 \pm 0.03^{e y}$ & $35.9 \pm 0.01^{a y}$ & $50.8 \pm 0.08^{e z}$ & $51.1 \pm 0.02^{f z}$ & $43.0 \pm 0.04^{c y}$ & $44.8 \pm 0.02^{d z}$ & $46.6 \pm 0.02^{e y}$ & $39.0 \pm 0.08^{b y}$ & $42.9 \pm 0.04^{c y}$ \\
\hline MUFA $-7 d$ & $49.0 \pm 0.06^{b y}$ & $54.4 \pm 0.03^{e z}$ & $43.4 \pm 0.09^{a y}$ & $48.9 \pm 0.02^{b y}$ & $49.2 \pm 0.03^{b y}$ & $42.2 \pm 0.08^{a y}$ & $51.4 \pm 0.03^{d z}$ & $50.4 \pm 0.06^{c z}$ & $50.9 \pm 0.02^{c z}$ \\
\hline PUFA - 1d & $7.5 \pm 0.03^{i z}$ & $5.5 \pm 0.01^{d z}$ & $5.2 \pm 0.08^{c z}$ & $6.5 \pm 0.02^{f z}$ & $6.3 \pm 0.04^{e z}$ & $4.7 \pm 0.02^{b z}$ & $7.7 \pm 0.02^{j z}$ & $6.7 \pm 0.08^{g z}$ & $1.4 \pm 0.04^{a y}$ \\
\hline PUFA - $1 d$ & $4.7 \pm 0.06^{e y}$ & $4.6 \pm 0.03^{e y}$ & $3.4 \pm 0.09^{b y}$ & $6.3 \pm 0.02^{f y}$ & $4.0 \pm 0.03^{c y}$ & $4.5 \pm 0.08^{e y}$ & $3.7 \pm \mathbf{0 . 0 3}^{c y}$ & $4.3 \pm 0.066^{d y}$ & $2.2 \pm 0.02^{a z}$ \\
\hline
\end{tabular}

* Different letters $(a, b, c, d, e, f, g, i)$ within the same row indicate significant differences $(\mathrm{p} \leq 0.05)$;

Different letters $(y, z)$ within the same column indicate significant differences $(\mathrm{p} \leq 0.05) ; \mathrm{n}=9$; SD - standard deviation; 
The established divergent differences in the fatty acid profiles of the three studied samples from muscle and perirenal adipose tissues, on the one hand, are probably due to the relatively small proportion of phospholipids (polar lipid fraction) compared to one of the nonpolar fats (triacylglycerols). On the other hand, the different content of MUFA in the two studied muscles and perirenal fat depends on the metabolic muscle type and the topographicanatomical specificity of the adipose tissue [40]. The complex influence of breed, age, and dietary conditions on the fatty acid composition of lipids in goat meat was also reported [39]. Additional research is needed to elucidate the nature of the interactions between these factors and the doses of phytonutrient supplements with antioxidant properties applied to growing-up lambs. It is important to consider the fact that adding polyphenolic compounds for a longer period or at higher doses can cause a prooxidant effect in meat and accelerate oxidative processes, including adversely affecting the fatty acid metabolism and composition [41]. It should also be borne in mind that ruminants' digestions associated with food fermentation and polyphenols are poorly absorbed in the ruminants $[2,42]$. This may require the administration of significantly higher doses than those used in monogastric animals.

\subsection{Color properties.}

Divergent significantly $(\mathrm{p} \leq 0.05)$ changes in the color properties measured in the samples were found in m. Longissimus dorsi and m. Semimembranosus, both on $1 \mathrm{~d}$ post mortem and after $7 \mathrm{~d}$ of storage (Table 3 ).

Table 3. Changes of the color properties of lambs' m. Longissimus dorsi and m. Semimembranosus after $7 \mathrm{~d}$ storage at $0-4^{\circ} \mathrm{C}$.

\begin{tabular}{l|l|l|l|l|l|l} 
Samples & m. Longissimus dorsi & \multicolumn{3}{l}{ m. Semimembranosus } \\
\hline & C & D & R & C & D \\
\hline $\mathrm{L}^{*}-1 \mathrm{~d}$ & $41.12 \pm 0.12^{a y}$ & $44.91 \pm 0.53^{d z}$ & $44.15 \pm 0.17^{c y}$ & $45.28 \pm 0.08^{e z}$ & $41.67 \pm 0.19^{b y}$ & $44.97 \pm 0.19^{d y}$ \\
\hline $\mathrm{L}^{*}-7 \mathrm{~d}$ & $43.27 \pm 0.58^{b z}$ & $42.60 \pm 0.37^{b y}$ & $46.60 \pm 1.06^{c z}$ & $40.75 \pm 0.86^{a y}$ & $42.48 \pm 0.45^{b z}$ & $46.12 \pm 0.44^{c z}$ \\
\hline $\mathrm{a}^{*}-1 \mathrm{~d}$ & $18.27 \pm 0.19^{c y}$ & $17.66 \pm 0.30^{b y}$ & $18.03 \pm 0.11^{b z}$ & $16.77 \pm 0.21^{a y}$ & $19.75 \pm 0.15^{e z}$ & $18.88 \pm 0.20^{d y}$ \\
\hline $\mathrm{a}^{*}-7 \mathrm{~d}$ & $19.33 \pm 0.40^{c z}$ & $19.10 \pm 0.27^{c z}$ & $17.75 \pm 1.13^{a y}$ & $19.70 \pm 0.64^{d z}$ & $18.98 \pm 0.13^{c y}$ & $18.73 \pm 0.21^{b y}$ \\
\hline $\mathrm{b}^{*}-1 \mathrm{~d}$ & $2.03 \pm 0.04^{a z}$ & $3.20 \pm 0.03^{c z}$ & $3.46 \pm 0.02^{d y}$ & $3.06 \pm 0.24^{c y}$ & $2.50 \pm 0.07^{b z}$ & $4.04 \pm 0.06^{e z}$ \\
\hline $\mathrm{b}^{*}-7 \mathrm{~d}$ & $1.95 \pm 0.51^{a y}$ & $2.33 \pm 0.19^{a y}$ & $3.93 \pm 0.13^{b z}$ & $3.87 \pm 0.19^{b z}$ & $2.37 \pm 0.05^{a y}$ & $3.70 \pm 0.21^{b y}$ \\
\hline$\Delta \mathrm{E}-1 \mathrm{~d}$ & & 4.01 & 3.36 & & 4.71 & 2.34 \\
\hline$\Delta \mathrm{E}-7 \mathrm{~d}$ & & 0.80 & 4.20 & & 2.40
\end{tabular}

* Different letters $(a, b, c, d, e)$ within the same row indicate significant differences $(\mathrm{p} \leq 0.05)$;

Different letters $(y, z)$ within the same column indicate significant differences $(\mathrm{p} \leq 0.05) ; \mathrm{n}=9$; SD - standard deviation;

Exceptions are the values for the brightness $\left(\mathrm{L}^{*}\right)$, the red $\left(\mathrm{a}^{*}\right)$, and the yellow $\left(\mathrm{b}^{*}\right)$ color component established in the controls $\mathrm{C}$ and samples $\mathrm{D}$ from $\mathrm{m}$. Longissimus dorsi after $7 \mathrm{~d}$ of chilled storage and the red ( $\left.\mathrm{a}^{*}\right)$ color component found on $1 \mathrm{~d}$ and $7 \mathrm{~d}$ of chilled storage in samples R of m. Semimembranosus. No significant ( $p>0.05$ ) differences were found between the levels of the indicated samples (Table 3). Neither of the two phytonutrients studied had a one-way effect on the color properties of the chilled lamb muscles. Compared to the controls $\mathrm{C}$ on $1 \mathrm{~d}$ post mortem, the total color difference $(\Delta \mathrm{E})$ in samples $\mathrm{D}$ was greater than the one found for samples R (4.01 and 4.71, respectively, compared to 3.36 and 2.34 for samples from $\mathrm{m}$. Longissimus dorsi and m. Semimembranosus, respectively). After $7 \mathrm{~d}$ of storage, the opposite trend was established. The $\Delta \mathrm{E}$ reported for samples $\mathrm{D}$ was significantly smaller $(0.80$ and 2.40) compared to the one found for samples $\mathrm{R}$ (4.20 and 5.46) respectively in $\mathrm{m}$. Longissimus dorsi and $\mathrm{m}$. Semimembranosus. The pigment responsible for meat color stability is the water-soluble sarcoplasmic protein myoglobin [27]. 
It undergoes auto-oxidative transformations. During refrigeration connected with exposure to oxygen from the air and light, iron and heme myoglobin are oxidized to metmyoglobin - a pigment with an unattractive grey-brown color [27]. An enzyme system was also found in the muscle tissue that exhibited metmyoglobin reductase activity (MRA). It is able to reduce metmyoglobin back to myoglobin [43]. In fresh meat ( $1 \mathrm{~d}$ post mortem), the enzyme retains high activity, and the formed metmyoglobin is rapidly reduced to deoxymyoglobin. During the 7 - day chilled storage of meat at $0-4{ }^{\circ} \mathrm{C}$ the activity of MRA does not decrease significantly. Under the action of oxygen and light on the surface of the meat, oxidative processes take place [31]. Initially, they are associated with the formation of oxymyoglobin, but as the shelf life progresses, it can self-oxidize iron from heme from $\mathrm{Fe}^{2+}$ to $\mathrm{Fe}^{3+}$ and thus be transformed into metmyoglobin [43]. Because all forms of myoglobin oxidation are interconnected, once the lipid peroxidation process is initiated, prooxidants are formed that react with oxymyoglobin and contribute to its conversion to metmyoglobin [17]. Since meat oxidation is an autocatalytic chain reaction initiated by lipid hydroperoxides that are transferred to the myoglobin fraction, we can relate the observed color changes to those of lipid oxidation found (Table 1).

\subsection{Microbiological status.}

On $1 \mathrm{~d}$ post mortem, no significant $(\mathrm{p}>0.05)$ differences were found in APC and in TYMC in any of the samples in m. Longissimus dorsi, m. Semimembranosus and perirenal adipose tissue (Table 4).

After $7 \mathrm{~d}$ of storage APC and TYMC of samples D and R in lamb's m. Longissimus dorsi, $\mathrm{m}$. Semimembranosus and perirenal adipose tissue were significantly $(\mathrm{p} \leq 0.05)$ smaller compared to controls C. The comparison between APC and resp. TYMC found in samples D, and $\mathrm{R}$ showed no significant ( $\mathrm{p}>0.05$ ) differences either in $\mathrm{m}$. Longissimus dorsi and $\mathrm{m}$. Semimembranosus or in perirenal fatty tissue.

Table 4. Changes of the aerobic plate count and total combined yeasts and molds count of lamb's $\mathrm{m}$.

Longissimus dorsi, m. Semimembranosus and perirenal fatty tissue after $7 \mathrm{~d}$ storage at $0-4{ }^{\circ} \mathrm{C}$.

\begin{tabular}{|c|c|c|c|c|c|c|c|c|c|}
\hline Samples & m. Longiss & mus dorsi & & m. Semim & nbranosus & & Perirenal f & tty tissue & \\
\hline Parameter & $\mathbf{C}$ & D & $\mathbf{R}$ & $\mathbf{C}$ & D & $\mathbf{R}$ & $\mathbf{C}$ & D & $\mathbf{R}$ \\
\hline APC, $\operatorname{lg~cfu/g~-~} 1 \mathrm{~d}$ & $\begin{array}{l}4.25 \\
0.07^{\text {ay }}\end{array} \quad \pm$ & $\begin{array}{l}4.20 \\
0.08^{a y}\end{array}$ & $\begin{array}{l}4.27 \\
0.04^{a y}\end{array}$ & $\begin{array}{l}4.27 \\
0.08^{a y}\end{array}$ & $\underset{a y}{4.25 \pm 0.06}$ & $\underset{a y}{4.26 \pm 0.05}$ & $\begin{array}{ll}5.11 & \pm \\
0.08^{a y} & \end{array}$ & $\underset{a y}{5.05 \pm 0.09}$ & ${\underset{a y}{a y}} .07 \pm 0.05$ \\
\hline APC, $\operatorname{lg~cfu/g}-7 d$ & $\begin{array}{ll}7.38 & \pm \\
0.07^{b z} & \end{array}$ & $\begin{array}{l}6.77 \\
0.10^{a z}\end{array}$ & $\begin{array}{l}6.74 \\
0.15^{a z}\end{array}$ & $\begin{array}{l}7.42 \quad \pm \\
0.08^{b z}\end{array}$ & $\underset{a z}{6.81 \pm 0.09}$ & $\begin{array}{ll}6.78 & \pm \\
0.11^{a z} & \end{array}$ & $\begin{array}{ll}7.18 & \pm \\
0.11^{b z} & \end{array}$ & $\begin{array}{ll}6.94 & \pm \\
0.12^{a z} & \end{array}$ & $\begin{array}{ll}6.91 & \pm \\
0.13^{a z} & \end{array}$ \\
\hline TYMC, lg cfu/g - 1d & $\begin{array}{l}4.31 \\
0.01^{a y}\end{array}$ & $\begin{array}{l}4.30 \\
0.03^{a y}\end{array}$ & $\begin{array}{l}4.25 \\
0.08^{a y}\end{array}$ & $\begin{array}{l}4.33 \\
0.03^{a y}\end{array}$ & $\underset{\text { ay }}{4.35 \pm 0.04}$ & $\underset{a y}{4.28 \pm 0.06}$ & $\begin{array}{ll}4.67 & \pm \\
0.03^{a y} & \end{array}$ & $\underset{a y}{4.66 \pm 0.05}$ & $\underset{a y}{4.61 \pm 0.09}$ \\
\hline TYMC, $\lg \mathrm{cfu} / \mathrm{g}-7 \mathrm{~d}$ & $\begin{array}{l}4.94 \\
0.06^{b z}\end{array}$ & $\begin{array}{l}4.58 \\
0.02^{a z}\end{array}$ & $\begin{array}{l}4.54 \\
0.03\end{array} \quad \pm$ & $\begin{array}{l}4.99 \\
0.07^{b z}\end{array}$ & $\begin{array}{l}4.59 \pm 0.04 \\
a z\end{array}$ & $\underset{a z}{4.58 \pm 0.02}$ & $\begin{array}{ll}5.03 & \pm \\
0.04^{b z} & \end{array}$ & $\underset{a z}{4.80 \pm 0.07}$ & $\underset{a z}{4.81 \pm 0.08}$ \\
\hline
\end{tabular}

* Different letters ( $a$ or $b$ ) within the same row indicate significant differences $(\mathrm{p} \leq 0.05)$;

Different letters ( $y$ or $z$ ) within the same column indicate significant differences $(\mathrm{p} \leq 0.05) ; \mathrm{n}=9$; SD - standard deviation;

Regardless of the relatively small doses of administration and the relatively short period of feeding with both phytonutrients, their intake had a certain bactericidal effect after seven days of storage of chilled lamb's m. Longissimus dorsi, m. Semimembranosus and perirenal fatty tissue. This effect is probably due to the antibacterial action of the flavonoids contained in the studied phytonutrients [44]. Our results agree with previously reported, according to which the total number of bacteria usually increases with the storage time and on $7 \mathrm{~d}$ after death does not exceed $108 \mathrm{cfu} / \mathrm{g}$ [30]. 
Dietary supplementation of lambs with $7.5 \mathrm{mg}$ dihydroquercetin/ $\mathrm{kg} / \mathrm{d}$ or $545 \mathrm{mg}$ $\mathrm{DDRP} / \mathrm{kg} / \mathrm{d}$ does not unidirectional affect the quality of chilled lamb after $7 \mathrm{~d}$ of storage. The POV levels in both Longissimus dorsi and Semimembranosus muscles and the perirenal adipose tissue did not depend on the supplementation of $7.5 \mathrm{mg}$ dihydroquercetin/ $\mathrm{kg} / \mathrm{d}$ to the lamb's diet.

On $1 \mathrm{~d}$ post mortem, the content of $\alpha$-aminoacidic nitrogen and APC and TYMC in the muscle and perirenal adipose tissue are not affected by the supplementation of the lamb's diet with any of the two phytonutrient supplements. On the contrary, TBARS was low and ranged within $0.4-0.7 \mathrm{mg} \mathrm{MDA} / \mathrm{kg}$ without a one-way trend, whereas the FFA of m. Longissimus dorsi with both supplements was reduced by about 1/6. In m. Semimembranosus and perirenal adipose tissue, only the supplementation of the lamb's diet with $545 \mathrm{mg}$ DDRP/kg/d had a similar reducing action of FFA.

After $7 \mathrm{~d}$ of storage, the supplementation of $545 \mathrm{mg}$ DDRP/kg/d to the lamb's diet contributed to a 2 - $6 \%$ decrease in $\mathrm{pH}$ in both muscle and perirenal fatty tissues; reduced the accumulation of $\alpha$-aminoacidic nitrogen by $7-14 \%$ and TBARS by more than $20 \%$ but only in $\mathrm{m}$. Longissimus dorsi and $\mathrm{m}$. Semimembranosus. Both studied phytonutrients supported the reduction of APC and TYMC in m. Longissimus dorsi and m. Semimembranosus as well as in the perirenal fatty tissue. In contrast, the reduction of FFA, approximately a $5 \%$ decrease in SFA at the expense of an increase in MUFA, and a smaller total color difference were found only with the supplementation of $7.5 \mathrm{mg}$ dihydroquercetin $/ \mathrm{kg} / \mathrm{d}$ to the lamb's diet as the established changes were more pronounced in m. Longissimus dorsi.

Further studies are needed to answer whether the use of higher doses of DDRP and dihydroquercetin as lamb's dietary supplements may be able to provoke a more pronounced inhibitory effect on lipid oxidation and fatty acid composition of meat and fats.

\section{Conclusions}

The supplemented by $545 \mathrm{mg}$ DDRP/kg life wight/d lamb's diet contributes for a reduction of $\alpha$-aminoacidic nitrogen and TBARS but only in $\mathrm{m}$. Longissimus dorsi and $\mathrm{m}$. Semimembranosus after $7 \mathrm{~d}$ of storage at $0-4{ }^{\circ} \mathrm{C}$. Both studied phytonutrients supported the reduction of APC and TYMC in $\mathrm{m}$. Longissimus dorsi and $\mathrm{m}$. Semimembranosus as well as in the perirenal fatty tissue. In contrast, the 5\%reduction of FFA, a decrease of SFA at the expense of an increase in MUFA, and a smaller total color difference were found only with the supplementation of $7.5 \mathrm{mg}$ dihydroquercetin/ $\mathrm{kg}$ life wight/d to the lamb's diet as the established changes were more pronounced in m. Longissimus dorsi. Further studies are needed to answer whether the use of higher doses of DDRP and dihydroquercetin as lamb's dietary supplements may be able to provoke a more pronounced inhibitory effect on lipid oxidation and fatty acid composition of meat and fats.

\section{Funding}

This research was funded by the Bulgarian National Science Fund (BNSF), Ministry of Education and Science of Republic of Bulgaria of state contract No DN 06/8 of 17 December 2016 "Study of the mechanism of biologically active compounds of plant origin accumulation in the organism of Bulgarian breed agricultural animals and their impact on the meat quality as a natural functional food". 


\section{Acknowledgments}

\section{The authors acknowledge the Bulgarian National Science Fund (BNSF) for their financial support of state contract No DN 06/8 of 17 December 2016 "Study of the mechanism of biologically active compounds of plant origin accumulation in the organism of Bulgarian breed agricultural animals and their impact on the meat quality as a natural functional food".}

\section{Conflicts of Interest}

The authors declare no conflict of interest.

\section{References}

1. Barton, M.D. Antibiotic use in animal feed and its impact on human health. Nutrition Research Reviews 2000, 13, 279-299, https://doi.org/10.1079/095442200108729106.

2. Celi, $\mathrm{P}$. The role of oxidative stress in small ruminants' health and production. Revista Brasileira de Zootecnia 2010, 39, 348-363, https://doi.org/10.1590/S1516-35982010001300038.

3. Patra, A.K.; Saxena, J. The effect and mode of action of saponins on the microbial populations and fermentation in the rumen and ruminant production. Nutrition Research Reviews 2009, 22, 204-219, https://doi.org/10.1017/S0954422409990163.

4. Singh, J.; Gaikwad, D.S. Natural Bioactive Products in Sustainable Agriculture. 1st ed.; Springer: Singapore, Singapore, 2020; pp. 273-289, https://doi.org/10.1007/978-981-15-3024-1_13.

5. Oh, J.; Wall, E.H.; Bravo, D.M.; Hristov, A.N. 1036 Phytonutrients as additives in ruminants: the unexpected target organ. Journal of Animal Science 2016, 94, 496-497, https://doi.org/10.2527/jam2016-1036.

6. Sunil, C.; Xu, B. An insight into the health-promoting effects of taxifolin (dihydroquercetin). Phytochemistry 2019, 166, 112066,6 https://doi.org/10.1016/j.phytochem.2019.112066.

7. Artem'eva, O.A.; Pereselkova, D.A.; Fomocheb, Y.P. Dihydroquercetin, the bioactive substance, to be used against pathogenic microorganisms as an alternative to antibiotics. Sel'skokhozyaistvennaya Biologya (Agricultural Biology) 2015, 50, 513-519, https://doi.org/10.15389/agrobiology.2015.4.513eng.

8. Vijayanchali, S.S. Nutrient, phytonutrient and antioxidant activity of the dried rose petals. Journal of Research, Extension and Development 2017, 6, 36-39.

9. Nowak, R.; Olech, M.; Pecio, Ł.; Oleszek, W. Cytotoxic, antioxidant, antimicrobial properties and chemical composition of rose petals. Journal of the Science of Food and Agriculture 2014, 94, 560-567, https://doi.org/10.1002/jsfa.6294.

10. Dragoev, S.G.; Balev, D.K.; Nenov, N.S.; Vassilev, K.P.; Vlahova-Vangelova, D.B. Antioxidant capacity of essential oil spice extracts versus ground spices and addition of antioxidants in Bulgarian type dry-fermented sausages. European Journal of Lipid Science and Technology 2016, 118, 1450-1462, https://doi.org/10.1002/ejlt.201500445.

11. Nychas, G.-J.E.; Skandamisa, P.N.; Tassou, C.C.; Koutsoumanis, K.P. Meat spoilage during distribution. Meat Science 2008, 78, 77-89, https://doi.org/10.1016/j.meatsci.2007.06.020.

12. Falowo, A.B.; Fayemi, P.O.; Muchenje, V. Natural antioxidants against lipid-protein oxidative deterioration in meat and meat products: A review. Food Research International 2014, 64, 171-181, https://doi.org/10.1016/j.foodres.2014.06.022.

13. Karre, L.; Lopez, K.; Getty, K.J. Natural antioxidants in meat and poultry products. Meat Science 2013, 94 , 220-227, https://doi.org/10.1016/j.meatsci.2013.01.007.

14. Dimitrova, M.; Ivanov, G.; Mihalev, K.; Slavchev, A.; Ivanova, I.; Vlaseva, R. Investigation of antimicrobial activity of polyphenol-enriched extracts against probiotic lactic acid bacteria. Food Science and Applied Biotechnology 2019, 2, 67-73, https://doi.org/10.30721/fsab2019.v2.i1.57.

15. Dragoev, S.G.; Staykov, A.S.; Vassilev, K.P.; Balev, D.K.; Vlahova-Vangelova, D.B. Improvement the quality and the shelf life of the high oxygen modified atmosphere packaged veal by superficial spraying with dihydroquercetin solution. International Journal of Food Science (Hindawi) 2014, 2014, https://doi.org/10.1155/2014/629062.

16. Surai, P.F. Polyphenol compounds in the chicken/animal diet: from the past to the future. Journal of Aanimal Physiology and Animal Nutrition 2014, 98, 19-31, https://doi.org/10.1111/jpn.12070.

17. Wanga, Z.; Tana, Y.; Cuia, X.; Changa, S.; Xiaoa, X.; Yanb, T.; Wangc, H.; Houa, F. Effect of different levels of selenium yeast on the antioxidant status, nutrient digestibility, selenium balances and nitrogen metabolism of Tibetan sheep in the Qinghai Tibetan plateau. Small ruminant research 2019, 180, 63-69, https://doi.org/10.1016/j.smallrumres.2019.10.001.

18. Stancheva, N.Zh.; Nakev, J.L.; Vlahova-Vangelova, D.B.; Balev, D.K.; Dragoev, S.G. Impact of Siberian larch dihydroquercetin or dry distilled rose petals as feed supplements on lamb's growth performance, carcass 
characteristics and blood count parameters. Iranian journal of applied animal science 2021, 11, 339-350, https://doi.org/10.31220/osf.io/ezr3s.

19. Smon, A.; Cuk, V.; Brecelj, J.; Murko, S.; Groselj, U.; Tansek, M.Z.; Battelino, T.; Lampret, B.R. Comparison of liquid chromatography with tandem mass spectrometry and ion-exchange chromatography by post-column ninhydrin derivatization for amino acid monitoring. Clinica Chimica Acta 2019, 495, 446-450, https://doi.org/10.1016/j.cca.2019.05.007.

20. Garrido, R.; Domínguez, R.; Lorenzo, J.M.; Franco, I.; Carballo, J. Effect of the length of salting time on the proteolytic changes in dry-cured lacón during ripening and on the sensory characteristics of the final product. Food Control 2012, 25, 789-796, https://doi.org/10.1016/j.foodcont.2011.11.036.

21. Kanda, H.; Hoshino, R.; Murakami, K.;Wahyudiono; Zheng, Q.; Goto, M. Lipid extraction from microalgae covered with biomineralized cell walls using liquefied dimethyl ether. Fuel 2020, 37, https://doi.org/10.1016/j.fuel.2019.116590.

22. Kardash, E.; Tur'yan, Y.I. Acid value determination in vegetable oils by indirect titration in aqueous-alcohol media. Croatica Chemica Acta 2005, 78, 99-103.

23. Wu, H.; Ghirmai, S.; Undeland, I. Stabilization of herring (Clupea harengus) by-products against lipid oxidation by rinsing and incubation with antioxidant solutions. Food Chemistry 2020, 316, https://doi.org/10.1016/j.foodchem.2020.126337.

24. Moutiq, R.; Misra, N.N.; Mendonça, A.; Keener, K. In-package decontamination of chicken breast using cold plasma technology: Microbial, quality and storage studies. Meat Science 2020, 159, https://doi.org/10.1016/j.meatsci.2019.107942.

25. ISO 12966-2:2011. Animal and vegetable fats and oils. Gas chromatography of fatty acid methyl esters - Part 2: Preparation of methyl esters of fatty acids. International Organization for Standardization: Geneva, Switzerland; 2011.

26. ISO 12966-1:2014. Animal and vegetable fats and oils. Gas chromatography of fatty acid methyl esters - Part 1: Guidelines on modern gas chromatography of fatty acid methyl esters. International Organization for Standardization: Geneva, Switzerland; 2014.

27. Hunt, M.C.; King, A. AMSA Meat Color Measurement Guidelines. American Meat Science Association: Champaign, Illinois, USA, 2012; pp. 1-135.

28. Tkacz, K.; Modzelewska-Kapituła, M.; Więk, A.; Nogalski, Z. The applicability of total color difference $\Delta \mathrm{E}$ for determining the blooming time in Longissimus lumborum and Semimembranosus muscles from HolsteinFriesian bulls at different ageing times. Applied Sciences 2020, 10, https://doi.org/10.3390/app10228215.

29. ISO 4833:2003. Microbiology of food and animal feeding stuffs - Horizontal method for the enumeration of microorganisms - Colony-count technique at 30 degrees $C ; 2003$.

30. Nakyinsige, K.; Sazili, A.Q.; Aghwan, Z.A.; Zulkifli, I.; Goh, Y.M.; Abu Bakar, F.; Sarah, S.A. Development of microbial spoilage and lipid and protein oxidation in rabbit meat. Meat Science 2015, 108, 126-131, https://doi.org/10.1016/j.meatsci.2015.05.029.

31. Orzechowski, A.; Ostaszewski, P.; Jank, M.; Berwid, S.J. Bioactive substances of plant origin in food impact on genomics. Reproduction Nutrition Development 2002, 42, 461-477, https://doi.org/10.1051/rnd:2002034.

32. Benjakul, S.; Visessanguan, W.; Thongkaew, C.; Tanaka, M. Comparative study on physicochemical changes of muscle proteins from some tropical fish during frozen storage. Food Research International 2003, 36, 787795, https://doi.org/10.1016/S0963-9969(03)00073-5.

33. Yi, G.; Haug, A.; Nyquist, N.F.; Egelandsdal, B. Hydroperoxide formation in different lean meats. Food Chemistry 2013, 141, 2656-2665, https://doi.org/10.1016/j.foodchem.2013.05.041.

34. Szliszka, E.; Krol, W. The role of dietary polyphenols in tumor necrosis factor-related apoptosis inducing ligand (TRAIL)-induced apoptosis for cancer chemoprevention. European Journal of Cancer Prevention 2011, 20, 63-69, https://doi.org/10.1097/CEJ.0b013e32833ecc48.

35. Papastergiadis, A.; Mubiru, E.; Van Langenhove, H.; De Meulenaer, B. Malondialdehyde measurement in oxidized foods: Evaluation of the spectrophotometric thiobarbituric acid reactive substances (TBARS) test in various foods. Journal of Agricultural and Food Chemistry 2012, 60, 9589-9594, https://doi.org/10.1021/jf302451c.

36. Duthie, G.; Morrice, P. Antioxidant capacity of flavonoids in hepatic microsomes is not reflected by antioxidant effects in vivo. Oxidative Medicine and Cellular Longevity 2012, 2012, https://doi.org/10.1155/2012/165127.

37. Stolpovskaya, E.V.; Trofimova, N.N.; Babkin, V.A. Evaluation of antioxidant activity of dihydroquercetin complexes with biogenic metal ions. Khimiya Rastitel'nogo Syr'ya [Russian Journal of Bioorganic Chemistry] 2017, 43, 742-746, https://doi.org/10.1134/S1068162017070160.

38. Descalzo, A.M.; Sancho, A.M. A review of natural antioxidants and their effects on oxidative status, odor and quality of fresh beef produced in Argentina. Meat Science 2008, 79, 423-436, https://doi.org/10.1016/j.meatsci.2007.12.006.

39. Banskalieva, T.; Sahlu, V.; Goetsch, A.L. Fatty acid composition of goat muscles and fat depots: a review. Small Ruminant Research 2000, 37, 255-268, https://doi.org/10.1016/S0921-4488(00)00128-0. 
40. Utrera, M.; Parra, V.; Estévez, M. Protein oxidation during frozen storage and subsequent processing of different beef muscles. Meat Science 2014, 96, 812-820, https://doi.org/10.1016/j.meatsci.2013.09.006.

41. Peña-Torres, E.F.; González-Ríos, H.; Avendaño-Reyes, L.; Valenzuela-Grijalva, N.V.; Pinelli-Saavedra, A.; Muhlia-Almazán, A.; Peña-Ramos, E.A. Hydroxycinnamic acids in animal production: pharmacokinetics, pharmacodynamics and growth promoting effects. Review. Revista mexicana de Ciencias Pecuarias 2019, 10, 391-415, https://doi.org/10.22319/rmcp.v10i2.4526.

42. Sabino, M.; Carmelo, V.A.O.; Mazzoni, G.; Cappelli, K.; Capomaccio, S.; Ajmone-Marsan, P.; VeriniSupplizi, A.; Trabalza-Marinucci, M.; Kadarmideen, H.N. Gene co-expression networks in liver and muscle transcriptome reveal sex-specific gene expression in lambs fed with a mix of essential oils. BMC Genomics 2018, 19, 1-15, https://doi.org/10.1186/s12864-018-4632-y.

43. Bekhit, A.E.D.; Faustman, C. Metmyoglobin reducing activity. Meat Science 2005, 71, 407-439, https://doi.org/10.1016/j.meatsci.2005.04.032.

44. Verri, Jr.W.A.; Vicentini, F.T.M.C.; Baracat, M.M.; Georgetti, S.R.; Cardoso, R.D.R.; Cunha, T.M.; Ferreira, S.H.; Cunha, F.Q.; Fonseca, M.J.V.; Casagrande, R. Flavonoids as Anti-Inflammatory and Analgesic Drugs: Mechanisms of Action and Perspectives in the Development of Pharmaceutical Forms. Book series: Studies in Natural Products Chemistry 2012, 36, 297-330, https://doi.org/10.1016/B978-0-444-53836-9.00026-8. 